\title{
To evaluate the water quality status and responsible factors for variation in Anchar Lake, Kashmir
}

\author{
Manderia Sushil, Jahangeer Mohd Reshi*, Manderia Krishna** \\ SOS Botany, Jiwaji University, Gwalior (M.P.) 474011 \\ *SS in Environment Management, Vikram University, Ujjain (M.P.) 456010 \\ **Department of Botany, P.M.B. Gujarati Science College, Indore (M.P.)
}

\begin{abstract}
The present study was carried out to evaluate the water quality status of Anchar lake Kashmir whole year from January 2013 to December 2013. Anchar lake, an urban shallow basin lake with a maximum depth of 2.6 meters was getting modified as a result of cultural eutrophication due to anthropogenic pressure, siltation and the effluent released from Sheri-Kashmir Institute of Medical Sciences (SKIMS). The physico-chemical characteristics assessed at seven selected sites for $\mathrm{pH}$, conductivity, temperature, depth, dissolved oxygen (DO), Total hardness, calcium hardness, magnesium hardness, free $\mathrm{CO}_{2}$, sulphate, phosphate, iron, ammonical nitrogen, sodium and potassium. Result shows positive correlation among all the physico-chemical parameters except DO. The study reveals that site 7 near SKIMS was highly nutrient rich with respect to other sites.
\end{abstract}

\section{Introduction}

Water is the Universal solvent, abundant and useful component, without it life is impossible. These water bodies are not only important for water, but also for their ecological importance as they provide habitat to aquatic flora and fauna including different species of birds. They may also comprise an important component for sustainable tourism and recreation. At present water resources are in a serious problem due to encroachment, unplanned urbanization and industrialization (Singh, et. al., 2002). Environmental status of lakes all over the World is in varying degrees of degradation. The Kashmir valley, in India is famous for its high mountain reaching to a height of 6000 meters, their elevations and depressions have created numerous, high altitude, fresh water lakes- The urban lakes of Kashmir including Anchar Lake are facing a serious threat of encroachment due to anthropogenic pressures resulting in their gradual eutrophication and degradation. The Anchar Lake is situated at an altitude of $1583 \mathrm{~m}$ above sea level and lies between $34^{\circ}-20^{\prime}$ to $34^{\circ}-36^{\prime} \mathrm{N}$ and $74^{\circ}-82^{\prime}$ to $74^{\circ}-85^{\prime} \mathrm{E}$ and is situated in semi urban conditions. The lake is located near Soura at a distance of $14 \mathrm{kms}$ north-west of Srinagar and is shallow with single basin. The lake is fed by Sindh Nallah and numerous small channels. Anchar Lake receives water also from Dal Lake through a Nallah named Amir Khan via Khushalsar Lake. Large areas surrounding the lake have been reclaimed for agricultural and habitational purposes. Paddy fields are present on its North- Western side. The lake is undergoing considerable shrinkage mainly due to human activities.

The objectives of the present study were to assess water quality status, factors responsible for variation and effect of effluents of SKIMS on water quality of the lake.

\section{Materials and methods}

The lake has an area of $4.26 \mathrm{Km}^{2}$ with a maximum depth of 2.6 meter (Fig.1). The lake was divided into seven sampling stations namely Sind out flow (Site 1), Center of lake (Site 2), Sind inflow (Site 3), Sandgul (Site 4), Manzcul (Site 5), Sangam (Site 6) and SKIMS (Site 7).

Water samples were collected on monthly basis from the lake at different selected sites in one liter polyethylene bottles properly cleaned and were analysed in laboratory for different physicochemical parameters as per APHA (1998).

Parameters like depth, transparency, temperature, $\mathrm{pH}$, conductivity and dissolved oxygen were recorded at sampling stations. Parameters like calcium, magnesium, free carbon dioxide, sulphate, phosphate, iron, ammonical nitrogen, sodium, potassium and hardness were analysed in laboratory. Study period were divided into four phase i.e. Phase Ist from January to March; Phase IInd from April to June; Phase IIIrd from July to September; Phase IVth from October to December.

\section{Results and Discussion}

The water temperature ranges between $10 \pm 0.5^{\circ} \mathrm{C}$ to $21 \pm 1^{\circ} \mathrm{C}$. The minimum of $10^{\circ} \mathrm{C}$ was recorded at sites 1,3,5,7 and maximum $21^{\circ} \mathrm{C}$ at site 2 during summer season (Fig.2). The high water temperature recorded is the result of low water depth and consequently the volume of water in contact with air as observed by Sankar $e t$ al., (2010) and Bhaskar et. al. (2003) in other eutrophic water bodies. 
The water depth ranged about $0.60 \pm 0.02$ meters to $2.5 \pm 0.2$ meters. The minimum depth of 0.60 was recorded at site 7 during phase Ist and the highest $(2.52 \pm 0.22 \mathrm{~m})$ at site 1 during phase IIIrd (Fig. 3). The depth does not show variation among the different sites. The minimum depth of 0.6 meters was observed at site 7 and is related to more erosion in catchment area resulting in accumulation of sediments, thus reducing the depth. The variation in the depth of water body may be attributed to the excessive varied siltation, shallow waters have been associated with production systems.

The $\mathrm{pH}$ of water fluctuated from $7.7 \pm 0.1$ to $8.5 \pm 0.1$. The lowest value $7.7 \pm 0.2$ was recorded during phase Ist, IIIrd \& IVth and the highest value $8.5 \pm 0.1$ at site 7 during phase IInd (Fig. 4). The high pH values are probably due to the production of salicylic acid by the hydrolysis of silicates in the rock beds of the catchment areas (Sankar et al., 2010)). It may also be attributed due to increased organic compound degradation which is high in the lake. The higher value of $\mathrm{pH}$ of (8.5) coincides with the period of higher photosynthetic activity by macrophytes which results in decrease of $\mathrm{H}^{+}$concentration.

The conductivity ranged from $275 \pm 5$ to $559 \pm 10$. The minimum value of $275 \pm 5$ was recorded at site 3 during phase IVth and maximum value of $559 \pm 10$ was recorded at site 7 during phase IVth (Fig.5). The overall high conductivity of Anchar Lake depicted high ionic concentration with maximum at site 7 . The higher values were related to the abundance of nutrients released from the wastewaters, in addition to the release from decomposition process of organic matter (macrophytes and animals). Increased electrical conductivity is regarded as pollution indicator in shallow lakes (Das et al., 2006).

The transparency ranged from $0.2 \pm 0.05$ meters to $1.28 \pm 0.1$ meters. The minimum value 0.25 meters was recorded at site 7 during phase IVth and maximum value of 1.28 at site 1 during phase IVth. The low transparency of lake water is due to siltation and blooms of planktonic algae (Thilaga et.al. 2005; Akuskar and Gaikwad 2006). The transparency of 0.2 meters clearly depicts silt load in Lake.

The total hardness exhibited a range of $168 \pm 5 \mathrm{mg} / \mathrm{l}$ to $555 \pm 13 \mathrm{mg} / \mathrm{l}$. The minimum value of $168 \pm 5 \mathrm{mg} / \mathrm{l}$ was recorded at site 4 during phase IVth while as the maximum $555 \pm 13 \mathrm{mg} / \mathrm{l}$ was recorded at site 7 during phase IInd (Fig. 6). The higher value is attributed to the inflow of effluent from SKIMS hospital where hardness was $555 \mathrm{mg} / \mathrm{L}$. The calcium, magnesium showed a decline from February to May this is probably due to assimilation of cations $(\mathrm{Ca}$ and $\mathrm{Mg}$ ) by macrophytes Bhandari, N. S. and Nayal, K. 2008 were also reported decrease in cation concentration due to the accumulation by macrophytes.

The calcium content ranged from $33 \pm 3 \mathrm{mg} / 1$ to $76.3 \pm 8 \mathrm{mg} / \mathrm{l}$. The minimum $33 \pm 3 \mathrm{mg} / \mathrm{l}$ was recorded at site 1 during phase IVth and maximum $76.3 \pm 8 \mathrm{mg} / \mathrm{l}$ at site 7 during phase IInd (Fig. 7). The magnesium value ranged from $19 \pm 2 \mathrm{mg} / \mathrm{l}$ to $50 \pm 6 \mathrm{mg} / \mathrm{l}$. The minimum value of $19 \pm 2 \mathrm{mg} / \mathrm{l}$ was observed at site 4 during phase IVth and maximum value of $50 \pm 6 \mathrm{mg} / \mathrm{l}$ was recorded at site 7 during phase IInd (Fig. 8) The source of calcium and magnesium can be attributed to presence of lime stone in catchment areas (Najar and Khan 2011a). However the low Magnesium content was possibly due to its up lake by the plants (Bhandari, N. S. and Nayal, K. 2008) there by confirming 3:1 for $\mathrm{Ca}$ and $\mathrm{Mg}$ recorded for other water bodies (Thilaga et.al., 2005; Akuskar, S. K. and Gaikwad, A.V. 2006).

The value of alkalinity varied from $116 \pm 5 \mathrm{mg} / \mathrm{l}$ to $412 \pm 10 \mathrm{mg} / \mathrm{l}$. The minimum value of $116 \pm 5 \mathrm{mg} / \mathrm{l}$ was recorded at site 3 and 5 during phase IVth and maximum value of $412 \pm 10 \mathrm{mg} / \mathrm{l}$ was recorded at site 7 in phase Ist (Fig. 9).Alkalinity of lake was mostly found to be greater than $140 \mathrm{mg} / \mathrm{l}$ with maximum at site 7 and therefore the water can be considered as nutrient rich (Mishra, A. and Tripathi, B. D., 2007). The excessive increase in the concentration of total alkalinity at site $7(412 \mathrm{mg} / \mathrm{l})$ may be attributed to chemicals present in the effluent which are drained into the lake from SKIMS.

The chloride concentration varied from $22 \pm 1.2 \mathrm{mg} / \mathrm{l}$ to $60 \pm 3.3 \mathrm{mg} / \mathrm{l}$. The minimum concentration of $22 \pm 1.2 \mathrm{mg} / \mathrm{l}$ was at site 2 and 3 during phase Ist and maximum $60 \pm 3.3$ was at site 7 during phase IInd (Fig. 10). Chloride concentration is an index of eutrophication (Kumar et. al. 2006) and also pollution caused by sewage and other waste outlets (Thilaga et. al. 2005; Shyamala, et. al. 2008; Mishra, A. and Tripathi, B. D. 2007). The high chloride concentration of the lake may be related to the presence of large amounts of organic matter of both allochthonous and autochthonous origin (Nath, D. and Srivastvava, N. P., 2001; Pandit 1999). It is clear that even a moderate level of chlorides cause sufficient water pollution. The highest concentration was at SKIMS site, an indicator of inorganic pollution, again owes its origin to the sewage wastes carrying detergents, sewage from human settlements and chemical wastes of the SKIMS drained into the lake (Shamim et. al. 2001 and Singh, R. K. and Singh, K. N. 2007; Fokmare, A. K. and Musaddiq, M. (2002).

The $\mathrm{CO}_{2}$ values vary from $12 \pm 0.9 \mathrm{mg} / \mathrm{l}$ to $32.4 \pm 3 \mathrm{mg} / \mathrm{l}$. The minimum value $12 \pm 0.9 \mathrm{mg} / \mathrm{l}$ was recorded at site 1 and 2 during phase Ist and maximum $32.4 \pm 3 \mathrm{mg} / 1$ was recorded at site 7 during phase IIIrd (Fig. 11). The carbon dioxide content of water depends upon the water temperature, depth, rate of respiration, decomposition of organic matter, chemical nature of the bottom and geographical features of the terrain surrounding the water body (Sakhare and Joshi 2002). During present study the higher value of free $\mathrm{CO}_{2}$ was recorded at site 7 and lower value was recorded at site 1 and 2 . The high value may be related to the municipal 
effluent and hospital waste from the SKIMS. Study of Najar and Khan (2011a) also reported wastewaters as main source of organic waste.

The dissolved Oxygen of the water body ranges about $3.1 \pm 0.5 \mathrm{mg} / \mathrm{l}$ to $5.5 \pm 0.2 \mathrm{mg} / \mathrm{l}$ with minimum value $3.1 \pm 0.5 \mathrm{mg} / \mathrm{l}$ was recorded at site 7 during phase IVth and highest value of $5.5 \pm 0.2 \mathrm{mg} / 1$ was recorded at site 1 during phase Ist (Fig. 12). The dissolved oxygen in water is temperature dependant (Khare and Jadav., 2008). Low value of dissolved oxygen is an indication of a tendency towards an anoxic condition. However in case of Anchar Lake the overall moderate content of dissolved oxygen correlates with the growth and abundance of macrophytes and phytoplankton of the lake releasing oxygen during photosynthesis. The low dissolved oxygen was recorded at site 7 which is mainly due to effluents released from SKIMS, adding large quantity of organic wastes which consume the dissolved oxygen. The values further deplete during summers because at high temperature, the oxygen holding capacity of water decreases (Shyamala et.al. 2008). Present observations are in agreement with Yogesh Shastri and Pendse (2001) and Shanthi et. al. (2002) as they reported domestic wastes as main source of pollution resulting anoxic conditions in water bodies.

The sodium concentration ranged from $01 \pm 0.01 \mathrm{mg} / \mathrm{l}$ to $14 \pm 2 \mathrm{mg} / \mathrm{l}$ with upper value of $14 \pm 2 \mathrm{mg} / \mathrm{l}$ was recorded at site 7 during phase Ist and lower value of $01 \pm 0.01 \mathrm{mg} / \mathrm{l}$ was recorded at sites $(1,2,3)$ during phase IInd; IIIrd and IVth respectively. The high content of sodium in the fresh waters owing its source to domestic sewage and effluents from SKIMS. Sharma et al. (2012) also reported domestic sewage and effluent as main source of sodium.

The Potassium concentration varied from $01 \pm 0.01 \mathrm{mg} / 1$ to $13 \pm 1.1 \mathrm{mg} / \mathrm{l}$ with a maximum value of $13 \pm 1.1 \mathrm{mg} / \mathrm{l}$ was recorded at site 7 during phase Ist and minimum value of $01 \pm 0.01 \mathrm{mg} / \mathrm{l}$ was recorded at site 1 during phase IVth. The higher value of $13 \mathrm{mg} / \mathrm{l}$ goes beyond the permissible limit of $10 \mathrm{mg} / \mathrm{L}$. Its higher values may be attributed to the agricultural runoff (Garg et. al. 2010).

The Phosphate values fluctuated from $123 \pm 2 \mu \mathrm{g} / \mathrm{l}$ to $543 \pm 13 \mu \mathrm{g} / \mathrm{l}$. The site 3 exhibited a minimum value of $123 \pm 2 \mu \mathrm{g} / \mathrm{l}$ during phase IVth and a maximum value of $543 \pm 13 \mu \mathrm{g} / \mathrm{l}$ at site 7 during phase Ist. Phosphorus is regarded as a key element in eutrophication process (Fokmare, A. K. and Musaddiq, M. 2002) and raw sewage is the source of phosphates in different lakes (Agrawal, et. al. 2000). In case of Anchar Lake, the maximum phosphate showed gradual increase from site 1 to site 7 (SKIMS) where the concentration ranged from 520 to $543 \mu \mathrm{g} / \mathrm{l}$ as the site is under fast influence. Further the higher values are attributed to the use of fertilizers in nearby agricultural fields. Similar results reported by Arvind Kumar (1995). Najar and Khan (2011a) also reported agricultural runoff as main source of pollution in Anchar Lake resulting in accelerated eutrophication phenomenon.

The Ammonical nitrogen concentration varied from $155 \pm 8 \mu \mathrm{g} / \mathrm{l}$ to $512 \pm 11 \mu \mathrm{g} / \mathrm{l}$. The minimum value $155 \pm 8 \mu \mathrm{g} / \mathrm{l}$ was recorded at site 2 during phase IVth and maximum value $512 \pm 11 \mu \mathrm{g} / \mathrm{l}$ was recorded at site 7 during phase Ist. Ammonical nitrogen may be considered favorable for fish productivity. But higher values of ammonical nitrogen that lie in the range of 522 to $523 \square \mathrm{g} / \mathrm{l}$ at SKIMS site is an indication of organic pollution and thus the waters are favorable for prolific growth of obnoxious weeds like Salvinia natans (Magudeswaran, P.N. and Ramchandaran, T. (2007). Further higher values may be attributed due to domestic sewage that contributes nutrients to the lake (Qadri et al. 1999; Nath, D. and Srivastvava, N. P., 2001) and use of fertilizer in nearby agricultural fields.

The sulphate concentration showed a range of $61 \pm 1.9 \mathrm{mg} / 1$ to $151 \pm 3.9 \mathrm{mg} / \mathrm{l}$. The minimum value of $61 \pm 1.9 \mathrm{mg} / \mathrm{l}$ was recorded at site 4 during phase IVth and maximum value of $151.9 \pm 3.9 \mathrm{mg} / \mathrm{l}$ was recorded at site 7 during phase IInd. The presence of sulphate in water in higher concentration is undesirable. Sulphate exhibited variation among the sites. The highest values were found near the site of SKIMS. This may be due to the effluents containing sulphate that increases the concentration in lake. Purandara et al. (2003) Nath, D. and Srivastvava, N. P. (2001) also reported higher values of sulphate due to mineral weathering of bed rocks.

The iron concentration ranges from $131 \pm 2.1 \mu \mathrm{g} / \mathrm{l}$ to $233 \pm 6.3 \mu \mathrm{g} / \mathrm{l}$. The minimum value $131 \pm 2.1 \mu \mathrm{g} / \mathrm{l}$ was recorded at site 4 during phase IVth and maximum value of $233 \pm 6.3 \mu \mathrm{g} / \mathrm{l}$ was recorded at site 7 during phase Ist. Iron in drinking water may be due to its geological sources, domestic discharges and also the runoff from the nearby agricultural fields. The iron concentration during the study was high at site 7 (233), which may be reputed to the effluent discharge from SKIMS and also agricultural runoff from the nearby fields. Najar and Khan (2011a) also reported higher values of iron due to nearby agricultural fields.

\section{Conclusion}

From the present study it is clear that the Anchar Lake is getting modified as a result of cultural eutrophication mainly from anthropogenic pressure, siltation and the effluents released from SKIMS complex. The condition of the lake has reached a critical stage from ecological angles and if proper conservation measures are not taken, the lake is likely to deteriorate further. Though the rate of pollution varies from site to site with maximum in area receiving wastewaters from SKIMS, yet the impacts has been actually observed throughout the lake resulting in undesirable changes being accompanied by wide environmental degradation. 
The site 7 i.e. SKIMS has clearly indicated that there is adverse impact of effluents from SKIMS which are ultimately released into the lake in addition to the solid waste, sewage from human habitation. The site is highly nutrient rich with respect to other sites. Thus it is quite evident that the hospital effluent and sewage from human habitation have altered the lake chemistry and also the trophic status of the lake. In conclusion, it is quite convincing that the lake shows signs of accelerated eutrophication due to heavy anthropogenic pressure, siltation, effluents released from SKIMS and waste disposal into the lake.

\section{References}

[1]. Akuskar, S. K. and Gaikwad, A.V. (2006). Physico-chemical analysis of Manjara dam back water of Manjara river Dhanegoan, Maharashtra. India. Ecol. Environ. and Conserv., 12(1): 73-74.

[2]. APHA (1998). Standard methods for the examination of water and waste water. American Public Health Association Washington $20^{\text {th }}$ edition, Washington DC (U.S.A.): 1-1193.

[3]. Avnish K.Verma and D.N. Saksena (2010). Assessment of Water quality and Pollution Status of Kalpi (Morar) River, Gwalior, Madhya Pradesh: with special reference To Conservation and Management plan. Asian J. Exp. Biol. Sci., 1(2): 419 -429.

[4]. Bhandari, N. S. and Nayal, K. 2008). Correlation Study on Physico-chemical parameters and quality assessment of Kosi river water, Uttarakhand. J. Chem., 2(5): 342-346.

[5]. Bhaskar, B., Mukherjee, S., Chakraborty, R. and Nanda, A. K. (2003). Physico-chemical and bacteriological investigation on the river Torsa of North Bengal. J. Environ. Biol., 24: 125-133.

[6]. Bhat A. S., Rather S. A. and Pandit A. K. (2001). Impact of Effluents from Sheri-Kashmir Institute of Medical Sciences (SKIMS), Soura on Anchar Lake. J. Res. Dev. 1: 30-37.

[7]. Bhat S. A. and Pandit A. K. (2002). Limnological Investigation of Anchar Lake, Kashmir. J. Res. Dev. 2: 13-24.

[8]. Chinnaiah B., Madhu V. and Babu M. R. (2011). Physico-chemical characteristics of Khajana and darmasagar lakes, in Adilabad, Andhrapradesh, India. .2(4): 674-676.

[9]. Ellis M. M. and Wastfall B. A. (1946). Determination of water quality. Fish and wild. Serv. U. S. Dept. Interior Res., 9: 1-122.

[10]. Fokmare, A. K. and Musaddiq, M. (2002). A study on Physico-chemical characteristics of Kakshi lake and Purna river wastes in Akola District of Maharashtra (India). Natl. Environ. Poll. Technol., 1: 261-263.

[11]. Garg R. K., Rao R. J., Uchchariya D., Shukla G. and Saksena D. N.(2010). Seasonal variations in water quality and major threats to Ramsagar reservoir, India. Afr. Jr. of Environ. Sci. Technol. 4920: 061-076.

[12]. Hujare M. S. (2008). Seasonal variations of physicochemical parameters in the perennial tank of Talsande, Maharastra. Ecotoxicol. Environ. Monit. 18 (3): 233-242.

[13]. Kagalou I., Tsimarakis G. and Paschos I. (2001). Water Chemistry and Biology in a shallow lake (Lake Pamvotis- Greece). Present State and Perspective. Global Nest: Int. J. 3(2): 85-94.

[14]. Kaul V. (1997). Limnological survey of Kashmir lakes with reference to trophic status and conservation. Int. J. Ecol. Environ Sci. 3: 2944.

[15]. Khare K. C. and Jadav M. S. (2008). Water Quality Assessment of Katraj lake, Pune (Maharastra, India): 292-299.

[16]. Kumar A. (1995). Some Limnological aspects of the fresh water tropical wetland of Santhal Pargana (Bihar) India. J. Envi. Poll. 2 (3): 137-141.

[17]. Kumar V, Arya S, Sankar P, Minakshi, Dhana A and Chanchal (2011). Water quality status of Historical Antiya Tall at Jhansi city as a primary data for sustainable approach. Res. Sci. Tech 3(8): 52-55.

[18]. Kumar, S. S, Puttaiah, E. T., Manjappa, S., Prakash, Naik, S. and Kumar, V. (2006). Water quality assessment of river Tunga, Karnataka. Environ. Eco., 24(5): 23-26.

[19]. Magudeswaran, P.N. and Ramchandaran, T. (2007). Water quality index of river Noyyal at Tripur, Tamilnadu, India. Natl. Environ. and Pollu. Technol., 6(1): 51-54.

[20]. Manjare S. A., Vhanalakar S. A. and Muley D. V. (2010). Analysis of Water Quality Using Physico-Chemical Parameters Tamdalge Tank in Kolhapur District, Maharastra.Int. J. of Adv. Biotec. \& Res. 1(2): 115-119.

[21]. Mishra, A. and Tripathi, B. D. (2007). Seasonal and temporal variation in physico-chemical and bacteriological characteristics of river Ganga in Varansi. Cuur. World Environ., 2(2): 149-154.

[22]. Moundiotiya C., Sisodia r., Kulshreshtha M. and Bhatia A. L.(2004). A case study of the Jamwa Ramgarh Wetland with special Reference to Physico-chemical proprteies of water and its Environs. J. of Environ. Hydrology. 12(24): 1-7.

[23]. Murtaza S., Aziz M. A., Ali S. M. F. and Hussain S. A.(2010). Impacts of Pollutants on PhysicoChemical Characteristics of Dal Lake under Temperate Conditions of Kashmir. 1-3.

[24]. Najar I. A. and Khan A. B.(2011). Assessment of Water Quality and identification of Pollution sources of Three Lakes in Kashmir, India, using Multivariate analysis. Environ Earth Sci. doi 10.1007/s12665-011-1458-1.

[25]. Nath, D. and Srivastvava, N. P. (2001). Physico chemical characteristics of Narmada for the stretch sandia to Mola in M.P. state in the context of construction of reservoirs on the river or its tributaries. J. Inland Fish, Soc. India,33(1): 17-24.

[26]. Pandit A. K. (1999). Freshwater ecosystems of the Himalayas, Parthenon Publishing, New York London.

[27]. Paramsivam M. and Srinivasan A. (1981). Changes in algal flora due to pollution in Cavery River. Indian J. Environ. Hlth 23(3): 222238.

[28]. Prakash C (1982). Water Quality of Keetham Lake (Soor Sarovar). J. Envi. Bio., 4 (4): 193-200.

[29]. Purandara B. K., Varadarajan N. and Jayasree K. (2003). Impact of sewage on ground water; a case study. Poll. Res. 22(2): 189-197.

[30]. Puri P. J., Yenkie M. K. N., Battalwar D. G., Gandhare N. V. and Dharorkar D. B. (2010). Study and interpretation of physicochemical characteristics of lake water quality in Nagpur city India. Rasayan J. Chem. 3(4): 800-810.

[31]. Puri P. J., Yenkie M. K. N., Sangal S. P., Gandhare N. V., Sarote G. B. and Dhanorkar D. B.(2011). Surface water (lakes) Quality Assessment in Nagpur City (India) based on water Quality index (WQI). 4, No.1: 43-48.

[32]. Rani R., Gupta B. K. and Srivastava K. B. L. (2004). Studies on water quality assessment in Santa City (M. P.). Seasonal parametric variations. Nat. Environ. and Poll. Tech., 3(4): 563-565.

[33]. Raut R., Sharma S. and Bajracharya R. M.(2012). Biotic Response to acidification of lakes-A Review, 8(1): 171-184.

[34]. Rawson D. S. (1955). Morphometry as dominant factor in the productivity of large lakes. Verh. Int. verein. Limnol. 12: 291-308.

[35]. Saad M. A. H.(2003). Impact of Diffuse Pollution on the Socio-Economic Development opportunities in the Coastal Nile Delta Lakes. Diffuse Pollution Conference Dublin: 81-85.

[36]. Sakhre V. B. and Joshi P. K. (2002). Ecology of Palas-Nilegaon Reservoir in Osmanabad District, Maharastra. J. Aquat. Biol. 18(2): $17-$ 22. 


\section{To evaluate the water quality status and responsible factors for variation in Anchar Lake, Kashmir}

[37]. Sangeta D. and Savita D. (2011). Hydro Chemical Changes in two Eutrophic Lakes of Central India after immersion of Durga and Ganesh Idol. (1): 38-45.

[38]. Sankar, R., Ramkumar, L., Rajkumar, M., Sun, S. and Ananthan, G.(2010). Seasonal variations in physico-chemical parameters and heavy metals in waters and sediments of Uppanar estuary, Nagapattinam, India. Journal of Environmental Biology, 31(5) : 681-686.

[39]. Shanthi K. K. Ramasamy and Lakshmana P. (2002). Hydrobiological study of Siganallur Lake at Coimbatore, India. J. Nat. Envi. Poll. Tec., 1(2): 97-101.

[40]. Sharip Z, Zakaria S, (2008). Lakes and Reservoir in Malaysia: Management and Research Challenges. 1349-1355.

[41]. Sharma A, Ranga M. M, Sharma P. C. (2010). Water Quality Status of Historical Gundolav Lake at Kishangarh as a Primary Data for Sustainable Management. South Asian Journal of Tourism \& Heritage 3(2): 149-158.

[42]. Sharma S., Yadav R. K., Saini Y. and Sharma S. (2011). Water Quality Status of Puskar Lake as a Primary data for sustainable Development. South Asian Journal of Tourism \& Heritage 4(2): 185-192.

[43]. Sharma, R., Jikka, J., Bajpai, N. and Waghela (2012). Impact of domestic sewage and industrial effluent on Water quality of the khan river, Indore (India). Poll. Res., 31(2) : 289-296.

[44]. Shyamala, G., Shivananad, K. P. and Babu, S. S. (2008). A Preliminary report on the physico chemical nature of water pollution in and around Erode own, Tamil Nadu. Natl. Environ. Pollu. Technol., 7(3): 555-559.

[45]. Simpi B., Hiremath S. M., Murthy K. N. S., Chandrashekarappa K. N., Patel A. N. and Puttiah E. T. (2011). Analysis of water quality using physicochemical parameters Hosahlli Tank in Shimoga District, Karnataka. India. Glibal J. Sci. Front. R. 11(3): 31-34.

[46]. Singh J. and Upadhay S. K. (2012). Seasonal variation in heavy metals in Ramgarh Lake, Gorakhpur, India. Int. J. Lakes and Rivers. 5(2): 63-74.

[47]. Singh, R. K. and Singh, K. N. (2007). Physico-chemical and biological analysis of Gomati river water affected by urban wastes. Mar. Sci. Res. India, 4(2): 233-236.

[48]. Sinha S. N. and Biswas M. (2011). Analysis of physico-chemical characteristics to study the water quality of a lake in Kalyani, West Bengal. J. Exp. Biol. Sci., 2(1): 18-22.

[49]. Solanki H. A., Verma P. U. and Chandawat D. K.(2011). Evaluating the water Quality of Malav Lake by mean of Physico-Chemical analysis. Lif. Sci. Leaflet 20: 944-955.

[50]. Swaranlatha S. and Narsingro A. (1998). Ecological studies of Banjara Lake with reference to water pollution. J. Envi. Biol. 19(2): 179186.

[51]. Thilaga, A., Subhashini, S., Sobhana, S. and Kumar K. L. (2005). Studies on nutrient content of the Ooty Lake with reference to pollution. Natl. Env. Poll. Technol., 4(2): 299-302.

[52]. Verghese, Mathew, Anil Chauhan and Naik L. P. (1992). Hydrobiological studies of a domestically polluted tropical pond. J. Poll. Res., 11(2): 95-100.

[53]. Verma P., Chandawat D., Gupta V. and Solanki H. (2012). Water quality analysis of an organically polluted lake by investigating different physical and chemical parameters. Int. J. Res. Chem. Environ. 2(1): 105-111.

[54]. Yogesh S. and Pendse D. C. (2001). Hydrobiological study of Dahikhura reservoir. J. Env. Bio., 22(1): 67-70.

[55]. Zutshi D. P., Subla B. A. and Khan M. A. (1980).Comparative limnology of nine lakes of Kashmir Himalayas.Hydrobiologia 72(1-2): $101-112$

Table 1. Physicochemical characteristics of the Anchar Lake for the month of January to March 2013 (Phase Ist)

\begin{tabular}{|l|l|c|r|r|r|r|r|r|r|}
\hline S.No & \multicolumn{1}{|c|}{ Parameter } & Units & Site 1 & Site 2 & Site 3 & Site 4 & Site 5 & Site 6 & Site 7 \\
\hline 1 & Air temperature & ${ }^{\circ} \mathrm{C}$ & 15 & 16 & 15 & 16 & 15 & 16 & 15 \\
\hline 2 & Water temperature & ${ }^{\circ} \mathrm{C}$ & 10 & 11 & 10 & 11 & 10 & 11 & 10 \\
\hline 3 & Depth & $\mathrm{m}$ & 2.45 & 2.4 & 1.21 & 1.2 & 0.75 & 1.8 & 0.6 \\
\hline 4 & $\mathrm{pH}$ & $\mu \mathrm{mhos}$ & 300 & 305 & 292 & 354 & 318 & 478 & 546 \\
\hline 5 & Conductivity & $\mathrm{m}$ & 1.2 & 1.1 & 0.76 & 0.9 & 0.56 & 0.75 & 0.29 \\
\hline 6 & Transparency & $\mathrm{mg} / 1$ & 180 & 230 & 240 & 197 & 230 & 378 & 555 \\
\hline 7 & Total hardness & $\mathrm{mg} / \mathrm{l}$ & 36 & 42 & 41 & 40 & 38 & 51 & 74 \\
\hline 8 & Calcium & $\mathrm{mg} / 1$ & 24 & 22 & 23 & 21 & 24 & 33 & 45 \\
\hline 9 & Magnesium & $\mathrm{mg} / 1$ & 137 & 144 & 132 & 141 & 132 & 190 & 412 \\
\hline 10 & Total alkalinity & $\mathrm{mg} / 1$ & 30 & 22 & 23 & 26 & 31 & 47 & 56 \\
\hline 11 & Chloride & $\mathrm{mg} / 1$ & 12 & 12 & 12.5 & 15 & 12.8 & 23.9 & 29 \\
\hline 12 & Free CO ${ }_{2}$ & $\mathrm{mg} / 1$ & 5.5 & 5 & 5.1 & 5 & 5 & 4 & 3.8 \\
\hline 13 & Dissolved Oxygen & $\mathrm{mg} / 1$ & 3 & 3 & 2 & 4 & 11 & 9 & 14 \\
\hline 14 & Sodium $\mathrm{N}^{+}$ & $\mathrm{mg} / \mathrm{l}$ & 3 & 4 & 6 & 4 & 4 & 8 & 13 \\
\hline 15 & Potassium $\mathrm{K}^{+}$ & $\mu \mathrm{g} / \mathrm{l}$ & 171 & 161 & 166 & 145 & 278 & 521 & 543 \\
\hline 16 & Phosphate & $\mu \mathrm{g} / \mathrm{l}$ & 221 & 212 & 234 & 245 & 321 & 434 & 512 \\
\hline 17 & Ammonical nitrogen & $\mathrm{mg} / 1$ & 89 & 98 & 96 & 76 & 69 & 94 & 161 \\
\hline 18 & Sulphate & $\mu \mathrm{g} / \mathrm{l}$ & 175 & 156 & 151 & 141 & 194 & 204 & 233 \\
\hline 19 & Iron Fe & & & & & & &
\end{tabular}


Table 2. Physicochemical characteristics of the Anchar Lake for the month of April to June 2013 (Phase IInd)

\begin{tabular}{|c|c|c|c|c|c|c|c|c|c|}
\hline S.No & Parameter & Units & Site 1 & Site 2 & Site 3 & Site 4 & Site 5 & Site 6 & Site 7 \\
\hline 1 & Air temperature & ${ }^{\circ} \mathrm{C}$ & 20 & 21 & 20 & 20 & 20 & 20 & 21 \\
\hline 2 & Water temperature & ${ }^{\circ} \mathrm{C}$ & 15 & 16 & 15 & 15 & 15 & 15 & 16 \\
\hline 3 & Depth & $\mathrm{m}$ & 2.46 & 2.43 & 1.24 & 1.21 & 0.762 & 1.82 & 0.62 \\
\hline 4 & $\mathrm{pH}$ & - & 7.8 & 7.9 & 7.8 & 8.3 & 8 & 8.1 & 8.5 \\
\hline 5 & Conductivity & $\mu$ mhos & 305 & 310 & 301 & 348 & 301 & 487.2 & 551 \\
\hline 6 & Transparency & $\mathrm{m}$ & 1.25 & 1.16 & 0.77 & 0.89 & 0.56 & 0.77 & 0.25 \\
\hline 7 & Total hardness & $\mathrm{mg} / \mathrm{l}$ & 184 & 220 & 232 & 186 & 212 & 360 & 524 \\
\hline 8 & Calcium & $\mathrm{mg} / \mathrm{l}$ & 44 & 42.6 & 43.4 & 41 & 39.3 & 50.6 & 76.3 \\
\hline 9 & Magnesium & $\mathrm{mg} / \mathrm{l}$ & 25 & 23 & 25 & 24 & 27 & 35 & 50 \\
\hline 10 & Total alkalinity & $\mathrm{mg} / \mathrm{l}$ & 140 & 148 & 136 & 140 & 136 & 186 & 410 \\
\hline 11 & Chloride & $\mathrm{mg} / \mathrm{l}$ & 28 & 26 & 24 & 28 & 32 & 50 & 60 \\
\hline 12 & Free $\mathrm{CO}_{2}$ & $\mathrm{mg} / \mathrm{l}$ & 12.3 & 13.2 & 13.2 & 17.6 & 13.2 & 26.4 & 30.8 \\
\hline 13 & Dissolved oxygen & $\mathrm{mg} / \mathrm{l}$ & 5 & 4.8 & 4.9 & 4.8 & 4 & 3.8 & 3.2 \\
\hline 14 & Sodium $\mathrm{N}^{+}$ & $\mathrm{mg} / \mathrm{l}$ & 2 & 1 & 2 & 3 & 8 & 7 & 12 \\
\hline 15 & Potassium $\mathrm{K}^{+}$ & $\mathrm{mg} / \mathrm{l}$ & 2 & 3 & 4 & 4 & 3 & 9 & 12 \\
\hline 16 & Phosphate & $\mu \mathrm{g} / 1$ & 151 & 155 & 135 & 262 & 240 & 455 & 525 \\
\hline 17 & Ammonical nitrogen & $\mu \mathrm{g} / 1$ & 195 & 190 & 192 & 210 & 285 & 375 & 472 \\
\hline 18 & Sulphate & $\mathrm{mg} / \mathrm{l}$ & 74.2 & 96.2 & 93.3 & 72.3 & 66.3 & 90.9 & 151.9 \\
\hline 19 & Iron $\mathrm{Fe}$ & $\mu \mathrm{g} / \mathrm{l}$ & 150 & 145 & 145 & 142 & 182 & 198 & 210 \\
\hline
\end{tabular}

Table 3. Physicochemical characteristics of the Anchar Lake for the month of July to September 2013 (Phase

\begin{tabular}{|c|c|c|c|c|c|c|c|c|c|}
\hline \multicolumn{10}{|c|}{ IIIrd) } \\
\hline S.No & Parameter & Units & Site 1 & Site 2 & Site 3 & Site 4 & Site 5 & Site 6 & Site 7 \\
\hline 1 & Air temperature & ${ }^{\circ} \mathrm{C}$ & 24 & 23 & 24 & 23 & 24 & 24 & 24 \\
\hline 2 & Water temperature & ${ }^{\circ} \mathrm{C}$ & 18 & 17 & 18 & 17 & 18 & 18 & 18 \\
\hline 3 & Depth & $\mathrm{m}$ & 2.52 & 2.49 & 1.28 & 1.21 & 0.731 & 1.85 & 0.62 \\
\hline 4 & $\mathrm{pH}$ & & 7.7 & 7.9 & 7.7 & 8.4 & 8.1 & 8 & 8.3 \\
\hline 5 & Conductivity & $\mu \mathrm{mhos}$ & 310 & 312 & 278 & 333 & 287 & 500 & 544 \\
\hline 6 & Transparency & $\mathrm{m}$ & 1.25 & 1.06 & 0.72 & 0.85 & 0.54 & 0.7 & 0.22 \\
\hline 7 & Total hardness & $\mathrm{mg} / \mathrm{l}$ & 174 & 215 & 225 & 178 & 196 & 341 & 534 \\
\hline 8 & Calcium & $\mathrm{mg} / \mathrm{l}$ & 38.9 & 40 & 44.2 & 41.8 & 42 & 46 & 64 \\
\hline 9 & Magnesium & $\mathrm{mg} / \mathrm{l}$ & 27 & 24 & 24.8 & 23.5 & 27.7 & 35.4 & 48.2 \\
\hline 10 & Total alkalinity & $\mathrm{mg} / \mathrm{l}$ & 134 & 142 & 132 & 138 & 142 & 181 & 398 \\
\hline 11 & Chloride & $\mathrm{mg} / \mathrm{l}$ & 30 & 32 & 34 & 26 & 28 & 42 & 52 \\
\hline 12 & Free $\mathrm{CO}_{2}$ & $\mathrm{mg} / \mathrm{l}$ & 13.2 & 13.2 & 17.6 & 20.8 & 16.2 & 23.5 & 32.4 \\
\hline 13 & Dissolved Oxygen & $\mathrm{mg} / \mathrm{l}$ & 5.2 & 4.9 & 5.2 & 4.8 & 4.2 & 3.9 & 3.3 \\
\hline 14 & Sodium $\mathrm{N}^{+}$ & $\mathrm{mg} / \mathrm{l}$ & 2 & 1 & 1 & 2 & 12 & 8 & 13 \\
\hline 15 & Potassium $\mathrm{K}^{+}$ & $\mathrm{mg} / \mathrm{l}$ & 3 & 2 & 5 & 6 & 4 & 6 & 8 \\
\hline 16 & Phosphate & $\mu \mathrm{g} / \mathrm{l}$ & 152 & 156 & 132 & 265 & 242 & 455 & 520 \\
\hline 17 & Ammonical nitrogen & $\mu \mathrm{g} / 1$ & 188 & 185 & 190 & 215 & 280 & 370 & 468 \\
\hline 18 & Sulphate & $\mathrm{mg} / \mathrm{l}$ & 67.9 & 78 & 94.3 & 63 & 76 & 81 & 137 \\
\hline 19 & Iron $\mathrm{Fe}$ & $\mu \mathrm{g} / 1$ & 151 & 144 & 140 & 138 & 175 & 182 & 211 \\
\hline
\end{tabular}




\section{To evaluate the water quality status and responsible factors for variation in Anchar Lake, Kashmir}

Table 4. Physicochemical characteristics of the Anchar Lake for the month of October to December 2013 (Phase IVth)

\begin{tabular}{|l|l|r|r|r|r|r|r|r|r|}
\hline S.No & \multicolumn{1}{|c|}{ Parameter } & Units & Site 1 & Site 2 & Site 3 & Site 4 & Site 5 & Site 6 & Site 7 \\
\hline 1 & Air temperature & ${ }^{\circ} \mathrm{C}$ & 24 & 25 & 23 & 24 & 23 & 24 & 24 \\
\hline 2 & Water temperature & ${ }^{\circ} \mathrm{C}$ & 20 & 21 & 19 & 20 & 19 & 20 & 20 \\
\hline 3 & Depth & $\mathrm{m}$ & 2.48 & 2.45 & 1.24 & 1.24 & 0.79 & 1.86 & 0.6 \\
\hline 4 & $\mathrm{pH}$ & 7.7 & 7.9 & 7.9 & 8.4 & 8 & 8.2 & 8.2 \\
\hline 5 & Conductivity & $\mu \mathrm{mhos}$ & 298 & 305 & 275 & 325 & 276 & 480 & 559 \\
\hline 6 & Transparency & $\mathrm{m}$ & 1.28 & 1 & 0.7 & 0.8 & 0.51 & 0.7 & 0.2 \\
\hline 7 & Total hardness & $\mathrm{mg} / \mathrm{l}$ & 170 & 210 & 215 & 168 & 180 & 298 & 510 \\
\hline 8 & Calcium & $\mathrm{mg} / \mathrm{l}$ & 33 & 35 & 36 & 37 & 36 & 42 & 56 \\
\hline 9 & Magnesium & $\mathrm{mg} / \mathrm{l}$ & 23 & 21 & 21 & 19 & 23 & 30 & 41 \\
\hline 10 & Total alkalinity & $\mathrm{mg} / \mathrm{l}$ & 128 & 121 & 116 & 121 & 116 & 166 & 377 \\
\hline 11 & Chloride & $\mathrm{mg} / \mathrm{l}$ & 25 & 24 & 22 & 24 & 36 & 40 & 54 \\
\hline 12 & Free $\mathrm{CO}_{2}$ & $\mathrm{mg} / \mathrm{l}$ & 14 & 12 & 15.3 & 21 & 17.3 & 22 & 26 \\
\hline 13 & Dissolved oxygen & $\mathrm{mg} / \mathrm{l}$ & 4 & 4.1 & 4.2 & 4.3 & 3.8 & 3.4 & 3.1 \\
\hline 14 & Sodium $\mathrm{N}^{+}$ & $\mathrm{mg} / \mathrm{l}$ & 1 & 1 & 1 & 2 & 6 & 6 & 8 \\
\hline 15 & Potassium $\mathrm{K}^{+}$ & $\mathrm{mg} / \mathrm{l}$ & 1 & 2 & 3 & 3 & 3 & 4 & 6 \\
\hline 16 & Phosphate & $\mu \mathrm{g} / \mathrm{l}$ & 132 & 141 & 123 & 229 & 221 & 412 & 498 \\
\hline 17 & Ammonical nitrogen & $\mu \mathrm{g} / \mathrm{l}$ & 165 & 155 & 172 & 198 & 256 & 331 & 421 \\
\hline 18 & Sulphate & $\mathrm{mg} / \mathrm{l}$ & 66 & 71 & 89 & 61 & 62 & 73 & 121 \\
\hline 19 & Iron Fe & $\mu \mathrm{g} / \mathrm{l}$ & 144 & 140 & 137 & 131 & 161 & 163 & 185 \\
\hline
\end{tabular}
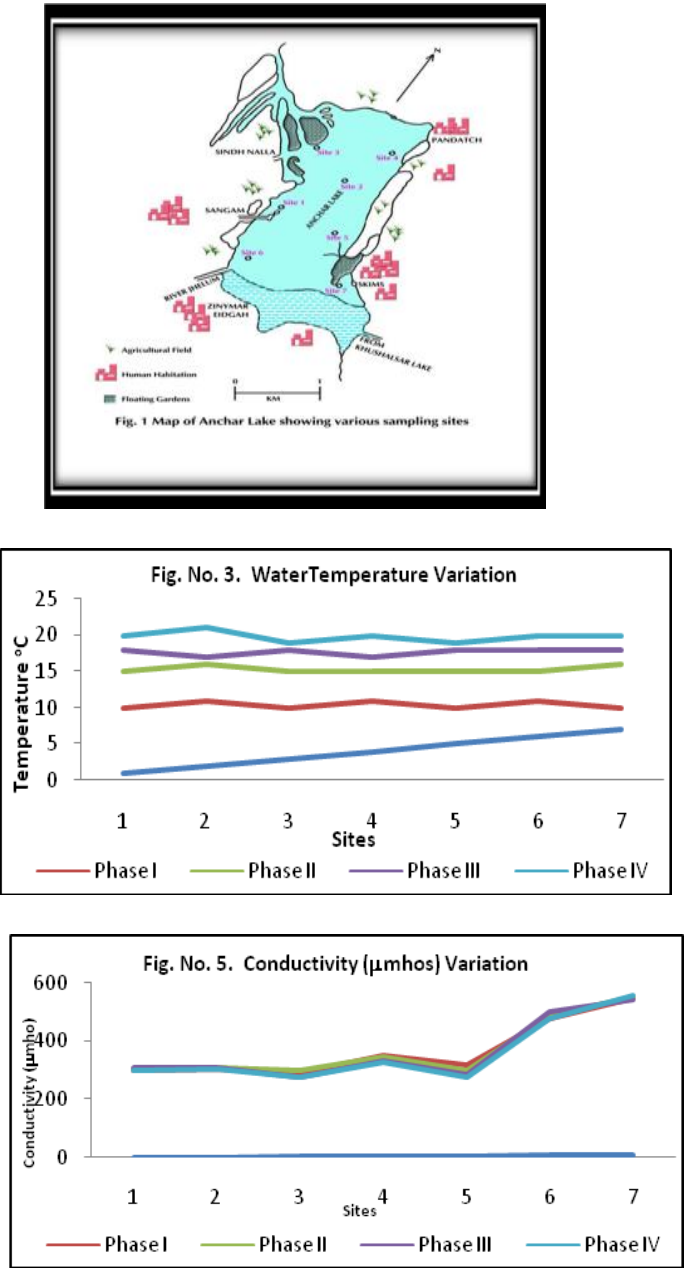
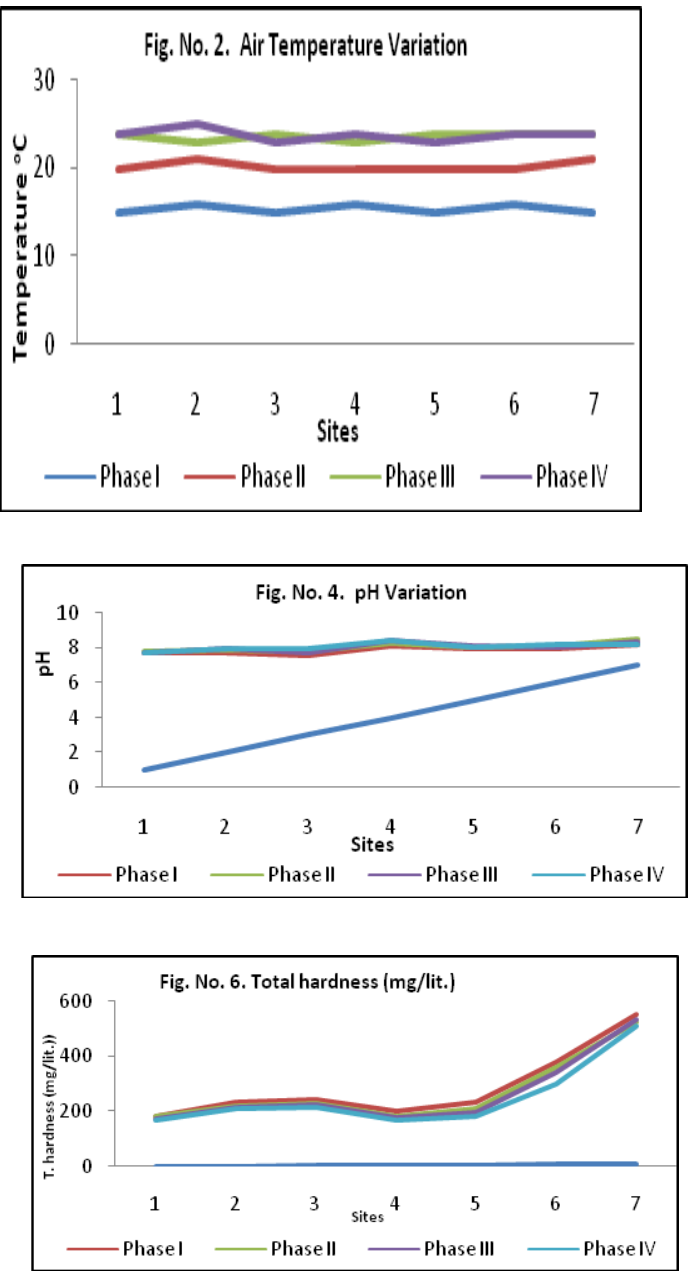

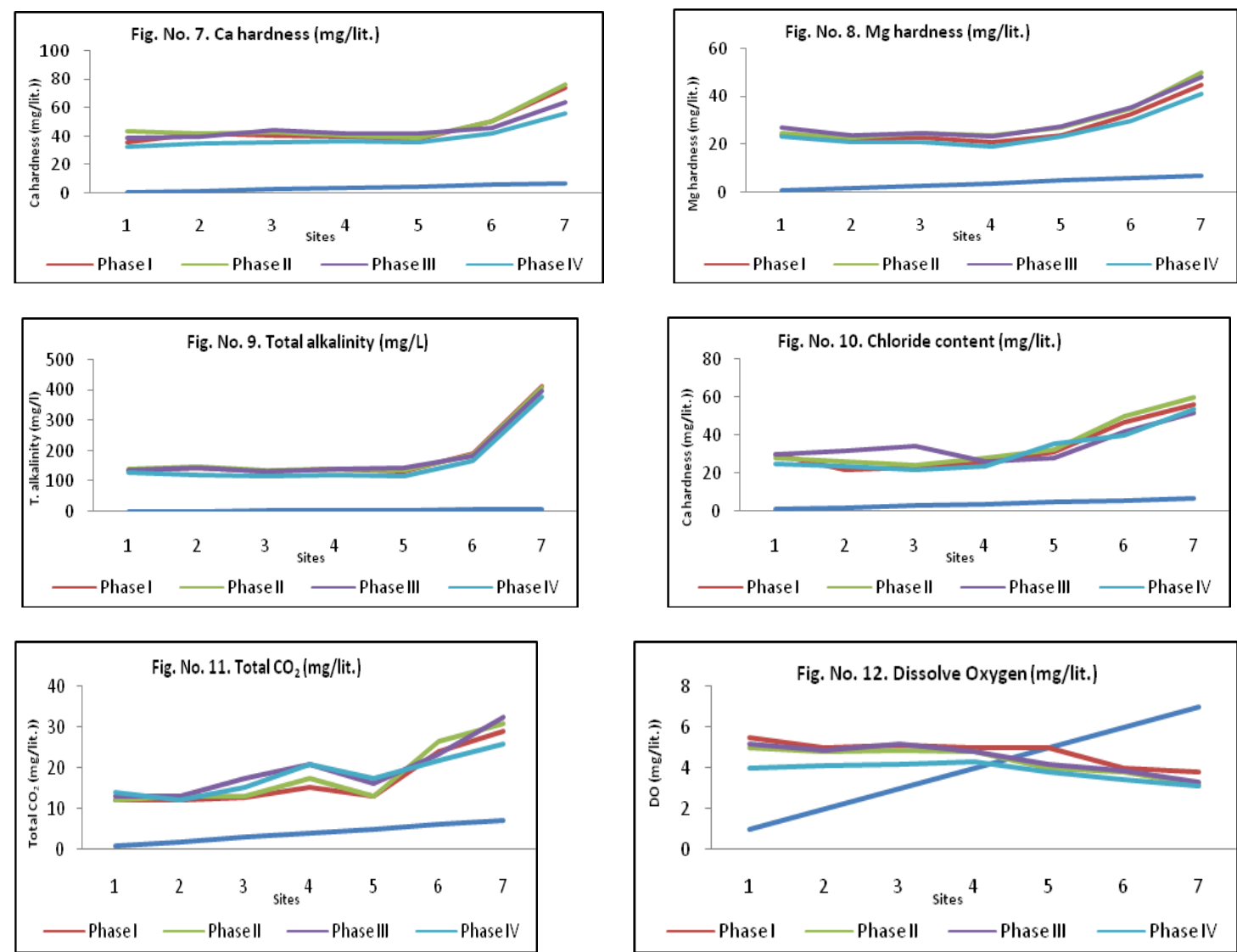